\title{
INFLUENCE UNDERSTANDING OF THE FINANCIAL MARKET'S FUNCTIONING TO THE COMMERCIAL AWARENESS OF ENTERPRISES: FOREIGN EXPERIENCE
}

\author{
Zerkal A., associate professor, Phd in Economics \\ Ukraine, Zaporizhzhya, Classic Private University, Deputy Head, Associate Professor of Finance, \\ Entrepreneurship and Stock Exchanges Department
}

DOI: https://doi.org/ 10.31435/rsglobal_ws/30122018/6270

\section{ARTICLE INFO}

Received: 04 October 2018

Accepted: 10 December 2018

Published: 30 December 2018

\section{KEYWORDS}

Commercial awareness,

bonds,

finance leasing,

enterprise,

bank,

finance market. \begin{abstract}
Basic financial knowledge goes a long way when contemplating the structuring of potential investments, as well as reviewing due diligence documentation prior to an investment being made. Being a public company opens up another avenue of finance, this time on the debt side. The principal types of bank are commercial (lending), investment (securities underwriting and trading) and bundled (both). Enterprises can usually borrow more cheaply by issuing a bond than by getting a loan from a bank, because a bondholder can simply sell the bond to get its money back whereas it is trickier for a bank to sell a loan (loans aren't designed to be bought and sold in quite the same way). An enterprise's staff is now required to play a more prominent role in business decisions rendered by an enterprise, as well as help shape their strategy and assist the enterprise to meet its corporate objectives
\end{abstract}

Citation: Zerkal A. (2018) Influence Understanding of the Financial Market's Functioning to the Commercial Awareness of Enterprises: Foreign Experience. World Science. 12(40), Vol.2. doi: 10.31435/rsglobal_ws/30122018/6270

Copyright: (C) 2018 Zerkal A. This is an open-access article distributed under the terms of the Creative Commons Attribution License (CC BY). The use, distribution or reproduction in other forums is permitted, provided the original author(s) or licensor are credited and that the original publication in this journal is cited, in accordance with accepted academic practice. No use, distribution or reproduction is permitted which does not comply with these terms.

Introduction. Commercial awareness does not only include industry specifications for the job you hold, but understanding of the workings of the business that your employer is in, and the varying contributing factors (be they national or international) that impact this business. Such knowledge can only be attained by taking a pro-active approach in getting to know the industry, by immersion into the environment and familiarizing oneself with the main players as well as their movements. Commercial awareness for staff is not only understanding an industry and a business though; it is also about having skills in other professional sectors as well - having a reasonable understanding of finance and accounting, as an example.

Research results. So far we have looked at equity raising through listing on the Stock Exchange. But being a public company opens up another avenue of finance, this time on the debt side. We already know that debt consists of loans. There is another type of debt: bonds.

A bond is basically an IOU which can be sold to someone else. This is why bonds are said to be tradable. The word 'bond' also means guarantee (my word is my bond) - as in 'posting a bond' to guarantee that something happens or someone behaves in a certain way. But in the financial markets it means a tradable 'I owe you' [1, p.137].

Only public companies can issue bonds. Private companies in the UK aren't allowed to issue bonds and, in any case, aren't big enough to raise the sort of amounts to make a bond issue worthwhile or to have the name recognition to make an issue successful. But public companies can and do.

Unlike loans (which are provided by banks), bonds are tradable, which means that institutional investors can buy and sell them - which is why the international bond market is global and huge, one of the biggest financial markets in the world. 
Enterprises aren't the only issuers. Governments are big issuers of bonds. In fact the biggest borrower in the world is the US government. Its bonds are called US treasuries because they are issued by the Treasury Department. UK government bonds are called gilts because they used to have a gilt edge as a mark of distinction [1, p.138].

Enterprises can usually borrow more cheaply by issuing a bond than by getting a loan from a bank, because a bondholder can simply sell the bond to get its money back whereas it is trickier for a bank to sell a loan (loans aren't designed to be bought and sold in quite the same way).

UK listed companies issue debentures which are registered bonds issued in the UK in sterling and listed on the London Stock Exchange as debt instruments. Debentures are often secured over the company's assets so that if the company defaults on the debenture, the holder can seize company assets and sell them to recover what it is owed (this is what lawyers call security but don't confuse it with securities which is the term used in the financial markets to mean bonds and shares). But the debenture market is domestic and relatively small [2, p.206].

By contrast, international bonds are bearer instruments (whoever holds a bond is treated as owning it). In the old days when they were issued as bits of card, they would have coupons attached that the holder would clip and return to the issuer in order to get the interest owed (that was the only proof required that you were the rightful recipient of the interest). This is why the interest payable on a bond is often called the coupon. The majority of bonds pay a fixed rate of interest throughout their life (e.g. 5\%) which is why bonds are often called fixed income instruments. Because the amounts in question are so large, the rate of interest is expressed in hundredths of a percentage, called basis points.

An international bond is issued by a company outside its home market and is often denominated in dollars (the currency of international finance and trade). Although bonds have been issued internationally for centuries, the current market dates from the 1960s when issues were made to tap dollars held on deposit in European banks - hence the term 'Eurodollar' and 'Eurobond' (which does not, yet, mean a bond denominated in euros).

In order to issue an international bond, a company has to get the issue rated by a credit rating agency (such as Standard \& Poor's, Moody's or Fitch). The rating agency will vet the company's financial position and 'rate' the issue in terms of the company's ability to service the debt (pay interest on it) and repay the principal. The rating agency (to which the issuer pays an annual fee as well as activity-based fees in relation to each rated issue) will continue to monitor the company's ability to meet the interest payments and repay the principal on maturity. Ratings range from 'triple A' (written 'AAA' or 'Aaa' depending on the rating agency) to 'below investment grade' ('Ba1' or 'BB+' or 'BB') and if the issuer's financial condition deteriorates or - in the language - its ability to service or repay becomes 'impaired', it may be immediately downrated [3].

The reason for this is that traders in the bond markets buy and sell at a moment's notice and want to know quickly whether the issuer is likely to default. They don't have time to undertake extensive credit analysis, unlike a lending bank which will pore over a company and its accounts before making a loan to it.

If the rating goes 'below investment grade', many of the institutional investors that hold the issue will have to sell (pension funds in particular are usually forbidden by their trust deeds to hold securities that are below investment grade). The market value of the bonds will go down as fewer institutions will want, or are able, to hold them. A more pejorative term for 'below investment grade' is junk bond or high-yield bond. There are banks and traders that specialise in buying junk bonds cheaply and holding them in the hope that the issuer's fortunes will recover and the bonds will be repaid in full.

But junk bonds are not bad in themselves. For example, a company may deliberately issue a shortterm, high-yield bond (paying a high rate of interest) to fund an M\&A deal - then if the takeover is successful, it will refinance the issue on more preferential terms when the takeover has been completed.

Bonds can have maturities ranging from 90 days to up to and beyond 20 years. Bonds of very short duration are called commercial paper. These issues are made by large, listed companies to fund a short-term working capital requirement (you see, it all connects). They usually have a maturity of just 90 days and don't pay interest. Instead they are issued at a discount to their face value: at the end of the 90 days the holder is paid the full face value. So if CP with a face value of 100 is issued at 99 , the company receives 99 and in three months' time pays back 100 . So for three months' money the company is paying $1 \%$, which equates to an annualised rate of $4 \%$.

What tends to happen at the end of the 90 days is that the CP is rolled over - the amount owing is repaid by a fresh issue of paper made to replace the paper that has expired. Commercial paper is bought by banks to park short-term deposits, but mainly by other large companies to invest short-term revenues that aren't immediately needed but will be soon.

Bonds with maturities over five years are called medium term notes or MTNs. They are often issued as part of an MTN programme where the company has a panel of three or four banks that have agreed to meet all of the company's debt requirements including loans and MTNs. The company decides at any point what it needs, tells the panel and the one offering the cheapest rate gets the business. 
Any bond over 10-12 years is called a long bond. As a general rule, the longer the tenor, the higher the rate of interest the company will pay to offset its credit risk because the longer the maturity, the less easy it is to predict what state the company is likely to be in when the bond expires [4, p.23].

Zero coupon bonds (also known as deep discount bonds) are issued without a coupon: they don't pay interest but are issued at a discount to their par or face value; on maturity the holder receives the face value. So, for example, a 5-year bond with a face value of 100 that is issued at 80 will reward the holder by paying an additional 20 on redemption, which is a $25 \%$ return over five years on the initial investment, or 5\% a year [5].

You still get loans in the international financial markets but these tend to be huge and because they are so big will be beyond a single bank to provide. So a company's bank will put together a syndicate of banks which between them will lend the company the money that it wants but on identical terms using a single syndicated loan agreement.

Each bank will go through its internal credit approval process, involving due diligence (examining the company's financial standing - due diligence also occurs in M\&A deals). Once the loan agreement has been negotiated and signed (this is called completion) the company can draw down the money provided it satisfies some conditions precedent (various legal opinions and certificates ensuring the documents are duly signed and the borrower is legally capable of borrowing).

During the life of the loan the company must comply with covenants (promises) in the loan agreement. Any breach by the company of the terms of the loan agreement is an event of default which allows the banks to accelerate the loan (ask for the money back early).

Possibly the trickiest term in the financial markets is the word 'bank'. It covers a multitude of different financial institutions which do different things. Banks are the source of debt funding.

A bank that makes loans is called a commercial bank. Commercial banks take deposits from people like you and me (our monthly salary cheque for example) and they lend us money (e.g. by way of overdraft). They pay us measly amounts of interest on money we deposit with them and charge us usurious rates of interest on any money we borrow. They keep the difference (this is called the margin or turn). Lending to you or me is called retail banking (it's the consumer market). Lending to companies is business-to-business or wholesale banking. Commercial banks also fund themselves by borrowing from each other on what is called the inter-bank market and the rate of interest they charge each other is LIBOR (London inter-bank offered rate) [1, p.160].

Then there are investment banks. These don't lend or invest. What they do is help companies and governments issue bonds: they advise them on how to issue bonds and at what price (this is called origination) and they underwrite the issue of those bonds. They also distribute those bonds to institutional investors. All of that activity is called primary market activity. Investment banks also buy and sell 'second-hand' bonds in what are called the secondary markets - where they act as marketmakers (being prepared to buy from or sell to investors, so providing a market for those bonds) and dealers (buying bonds for their own account).

Investment banks now do the same for shares (for instance in arranging, underwriting and distributing the shares in IPOs), but they didn't always do this. In the UK this was traditionally done by merchant banks, which helped businesses trade internationally by providing letters of credit and trade finance. This knowledge of their corporate clients enabled merchant banks to advise them on raising equity finance and M\&A deals (together called corporate finance) and on investing their profits and pension funds (called fund management).

Merchant banks have now all but disappeared - taken over by commercial and investment banks. In fact the biggest banks in the world combine all these activities - commercial, merchant and investment banking - and are called bundled, conglomerate or universal banks. Occasionally banks' credit ratings dip below those of their corporate customers - for instance, if the industry is in a periodic downturn.

Then companies can tap institutional investors for funds directly, bypassing banks. This is disintermediation and banks hate it.

One of the growth areas for syndicated loans is in M\&A transactions, where bank lending is called acquisition finance. As you now know, acquisitions are traditionally funded by the buyer's equity ('paper') in a share-for-share acquisition. But debt finance is often more attractive to:

- the target's shareholders (they get money not the buyer's shares)

- the buyer, since the costs are tax- deductible (whereas dividends are paid out of after-tax income)

- the buyer's shareholders, since any additional issue of equity may depress the buyer's earnings-per-share (since there are more shares in issue) which is a key profitability figure.

The debt can be provided as a loan. But high-yield bonds are also used in acquisition finance to fund an M\&A deal for a short period until it is refinanced with a loan or bond at a lower rate of interest.

Acquisition finance is also used to fund MBOs and LBOs. Sometimes a bank may want the option of turning its loan (or part of the loan) into shares if the bought- out business does well, in which case that debt is called mezzanine finance (mezzanine is a floor that's mid-way between two 
others; so this type of debt is mid-way between debt and equity). It is convertible from debt into equity, which is what convertible bonds are.

A lot of businesses don't actually own the assets they use. Whereas you and I might want to own the place we live in or the car we drive, businesses aren't interested in ownership provided they have the economic use of the asset. So instead of borrowing money to buy an asset (such as an aircraft in the case of an airline or an oil rig if you're an oil company), they get the bank to buy it and then lease it to them. This is like renting a flat rather than buying it with a mortgage - you never end up owning it.

This can actually be cheaper than borrowing and buying, for two reasons. The first is that the bank actually owns the asset so it feels more secure, which means it is exposed to less risk (if the company defaults, the bank owns the asset so can easily grab it back). This in turn means that it will charge less by way of rental under the lease than it would have by way of interest under a loan. The second is that the government gives tax advantages for capital investment (as buying big assets for use in business is called) in order to encourage business to invest in itself and remain competitive internationally. These tax advantages are passed on, in part, by the bank - in effect reducing the rental payable under the lease.

What happens is that the company enters into the lease with the bank. The lease term (length) is for the useful economic life of the asset (say 15 years). By the end of that primary term (as the lease period is called) the bank has been paid out - in other words the company's payments of rental (usually quarterly) have paid back the bank the cost of the asset and the interest on the principal over the 15 years (in this sense the payments work just like a mortgage - the further along you get, the greater the part of the payments that is paying off the principal cost of the asset).

So after 15 years the asset is either sold in the second-hand market and the company leases a new one; or it can continue to lease the asset but at a peppercorn rent (i.e. next-to-nothing since the bank has already been repaid). During the course of the lease, the company is required to maintain and insure the asset (almost as if it owned it) and is prevented from selling or charging the asset to anyone else (since the bank is the owner) [2, p.206].

You'd be surprised how many things are leased: most airlines lease rather than own their planes; most train companies lease their carriages. Virtually anything can be leased provided it is used in a business context. This includes oil rigs and ships on the one hand and audio recordings and films on the other.

Finance leasing should not be confused with operating leases. If you rent a car when you go on holiday, that is an operating lease: it's not for the car's useful economic life and you certainly don't expect to maintain it or insure it. The hire company does that.

By the way, hire-purchase and conditional sale are similar to finance leasing but they are different from it in that legal title to the asset does pass so the company does end up owning the asset.

You may come across sale-and-leaseback transactions. These are a form of asset finance in that a company which, say, owns its office may sell the office to a bank and then rent it back, in order to realise its capital investment in the office - i.e. get a lump sum out of the office. The idea here is that unless a company's core business is property ownership, it should not be a land owner but should instead use that capital in its main business.

Conclusions. It is only with such familiarity with the related industries, that a staff can be effective in understanding legal and commercial risks and how to mitigate them. Furthermore, basic financial knowledge goes a long way when contemplating the structuring of potential investments, as well as reviewing due diligence documentation prior to an investment being made.

Today, businesses operate in a very prescriptive and regulated business environment. This has meant that an enterprise's staff is now required to play a more prominent role in business decisions rendered by an enterprise, as well as help shape their strategy and assist the enterprise to meet its corporate objectives. An informed staff, engages with all business units to gage a feel for the enterprise's status and anticipate problems before they occur.

\section{REFERENCES}

1. Chan, K. C., Karolyi, G. A., \& Stulz, R. M. (1992). Global financial markets and the risk premium on U.S. equity. Journal of Financial Economics, 32, 137-168.

2. Block, N. (2002), "Concepts of consciousness", in Chalmers, D.J. (Ed.), Philosophy of Mind: Classical and Contemporary Readings, Oxford University Press, Oxford, pp. 206-18.

3. Karolyi, G. A., \& Stulz, R. M. (2002). Are financial assets priced locally or globally? NBER Working Paper No. 8994.

4. Ray, G., Barney, J.B. and Muhanna, W.A. (2004), "Capabilities, business processes, and competitive advantage: choosing the dependent variable in empirical tests of the resource-based view", Strategic Management Journal, Vol. 25, pp. 23-37.

5. Michelli, J.A. (2007), The Starbucks Experience: 5 Principles for Turning Ordinary into Extraordinary, McGraw-Hill, New York, NY. 